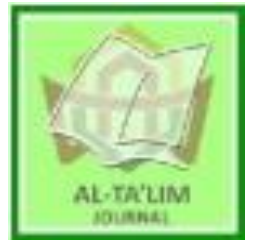

AL-TA'LIM JOURNAL, 27 (3), 2020, (250-257)

(Print ISSN 1410-7546 Online ISSN 2355-7893)

Available online at http://journal.tarbiyahiainib.ac.id/index.php/attalim

\title{
University Students' Perception on the Verbal Interaction in WhatsApp Chat Group
}

Received: $20^{\text {th }}$ March 2020; Revised: $26^{\text {th }}$ April 2020; Accepted: $19^{\text {th }}$ November 2020

Permalink/DOI: https://doi.org/10.15548/jt.v27i3.633

\section{Sujarwo*)}

Universitas Magarezy, Makasar, Indonesia

E-mail: jarwo.ibrahim@gmail.com

\section{Sukmawati}

Universitas Magarezy, Makasar, Indonesia

Email: sukmar.dilla@gmail.com

\section{Asdar}

Universitas Basowa, Makasar, Indonesia

E-mail: adam.asdar@yahoo.co.id

\section{Nina Ariani}

Hattyaiwittayalai school, Tambon Hat yai, Hat Yai District, Songkhla 90110.

Thailand

E-mail: inayunchu@gmail.com

\begin{abstract}
Verbal interactions will occur when both lecturer and learners could completely understand what each other means. It happens verbally among the teacher and learners during the teaching and learning activity. This study aims to examine the university students' perception on verbal interaction through WhatsApp chat group. A qualitative descriptive method was used to achieve the objective of this study. Observation and a questionnaire were employed as tools for data collection. A total number of 14 English as a Foreign Language (EFL) learners involved in this study. The finding revealed that university students'perception on verbal interaction gave the positive feedba ck towards WhatsApp chat group. This proves that ordinarily learners selected agree with utilizing WhatsApp chat group in doing verbal interaction. Hence, utilizing of WhatsApp chat group can be recommended as an efficient technique in verbal interaction for teaching and learning process.
\end{abstract}

\section{*) Corresponding Author}

Keywords: University students' perception; verbal interaction; WhatsApp chat group.

How to Cite: Sujarwo, S., Sukmawati, S., Asdar, A., Siradjuddin, S., \& Ariani, N. (2020). University Students' Perception on the Verbal Interaction through WhatsApp Chat Group. Al-Ta lim Journal, 27(3), 250-257. doi:https://doi.org/10.15548/jt.v27i3.633

\section{INTRODUCTION}

Examining the way in which the people speak has constantly been important. Whether it is verbal or non-verbal communication, conveying a message to other men and women is fundamental for human grasp and interaction. It not only helps us apprehend what they are saying, but it also helps us to categorical our feelings, emotions, and desires (Sham et al., 2017). According to Brown (2001) defines interaction as the collaborative exchange of thoughts, feelings, or ideas between two or more people, resulting in a reciprocal effect on each other. Successful verbal interactions will occur when both the teacher and learners could completely understand what each other means (Eliasoph \& Lichterman, 2003; Hymes, 2005). It happens verbally among the teacher and learners during the teaching learning activity (Mardiana et al., 2019). Interaction is a necessary activity for human beings to connect ideas and knowledge building. The view is also supported by Vygotsky's social constructivism that suggests knowledge 
formed and acquired through active interactions with members of society, such as one's colleagues or adults, rather than through individual cognitive activities (Lim et al., 2019).

Interaction is the way to get information. Verbal interaction especially, is the most important thing for the second language learners to get and learn language in order to communicate in the target language. Verbal interactions that occur in the classroom are the main structures that often create a quality learning environment or damage it (Downer et al., 2010; Minalla, 2018a; Pielmeier et al., 2018). The listener can understand the utterances of others, connect the things heard with his own understanding and resolve contradictions, if any, or if the contradictions that arise later on. Interaction happens when there is understanding between two or more people than giving responds. In learning the second language, this is the most important aspect that must be achieved by the learners (Taloko, 2011). Through the interaction, beginners have possibilities to apprehend and use the language that became incomprehensible.

Additionally, they may get extra input and extra opportunities for output (Yanfen \& Yuqin, 2010). Social interaction model happened in teaching and learning process. The interactions among students are mostly carried out using language, which is the outcome of personal thinking (Ernest, 1994; Hennessy, 1993). Many studies have been conducted to analyze the verbal interactions among the members of small student groups carrying out scientific inquiry activities (Anderson et al., 2001 as cited in (Lim et al., 2019). WhatsApp Inc. was established on February 29, 2009 in California, USA. The first product WhatsApp messenger, a crossplatform application that offers a service to send messages without having to pay fees. The name WhatsApp itself is inspired by the phrase "what's up!" or "how are you ?!"(WhatsApp, 2015 as cited in (Okditazeini \& Irwansyah, 2018). using mobile messaging purposes (such as LINE, Instagram, in unique WhatsApp) has received increasing popularity among young customers in Arab countries. This social community has opened up new opportu nities of interaction and collaboration between teachers and new comers in particular in language learning. So, with the growth of WhatsApp popularity, WhatsApp businesses may also make contribution in expanding possibilities of verbal interaction through voice message (Minalla, 2018b). Mistar and Amin Embi (2016) reported that WhatsApp is the most popular communication platform in the 21 st century depending on the fact that it uses real-time messages and fast knowledge resources and Ramakrishnan and Johnsi Priya (2016) found that WhatsApp ranks at the top unlike the other applications as cited in (Khaled Abdel Jaleel Dweikat, 2019).

According to a observe in the international Journal of Mobile Learning of Mobile Learning and Organization, results display that once WhatsApp became used within the classroom there was an growth in spelling, grammar, and vocabulary credited to the on the spot messaging spell checker in addition to an boom in student's motivation to write (Kootbodien et al., 2018). Meanwhile, perception is also identified as a system of receiving selecting, organizing, interpreting, testing, and giving a reaction to an object, event or problem. Perception is a method this is preceded by means of sensing, which is a stimulus acquired by using a person through a receptor, namely the senses. So, Perception is a process that is preceded by sensing, which is a stimulus received by an individual through a receptor, namely the senses.

This current study fills a gap that through verbal interaction that is carried out in virtual space, heterogeneous communities that are 'trapped' in common community carried out many researches. This study aims to find out verbal interaction model through WhatsApp chat group in university learners. Furthermore, EFL learners can create their

In latest years, verbal interaction by 
perception of verbal interaction through WhatsApp chat group in virtual space.

\section{METHOD}

\section{Research Design}

This research was conducted by using descriptive qualitative research which is adapted from that descriptive qualitative research is exploring and understanding of individual or group thinking ascribe to social or human problem (Creswell, 2009). Then, qualitative research is a research method that produces descriptive data in the form of written or oral words of the object under study and observed behaviour (Bogdan and Taylor as cited in (Harahap et al., 2018). Thus, qualitative data analysis was used to provide a better chance to attain reliable findings.

\section{Subjects}

The population of the study are EFL learners in the fourth semester of Universitas Megarezky who almost at the same age as well as having the same background knowledge of English. This study used saturation sample with the total numbers of 14 EFL learners who enrolled at academic year 2019/2020. They were in a WhatsApp chat group. Participants were almost in the same age as well as having the same background knowledge of English. In this respects, verbal interaction consisted of initiation, respond and follow up move.

\section{Instrument}

There were two instruments of this study namely questionnaire and observation. Those were used to achieve the objective of the study. Questionnaire was obtained by google form that was sent to WhatsApp chat group. This described how learners' perspective in doing verbal interaction through WhatsApp chat group. Then observation was conducted during teaching learning process taking place through WhatsApp chat group. The result of chats with learners and teacher became the result of observation. These were given code based on items of verbal interaction.

\section{RESULTS AND DISCUSSION}

\begin{abstract}
Verbal interaction consists of initiation, respond and follow up as assessment of this research. Initiation consists of question, direction and invitation. Respond describes how learners anwer question from teacher. Follow up describes about inform, comment, criticizing, acknowledgement, and ignoring. Charts below described how learners' perspective about verbal interaction through WhatsApp chat group.
\end{abstract}

\section{Initiation}

Items relating to initiation was analyzed as follow as:

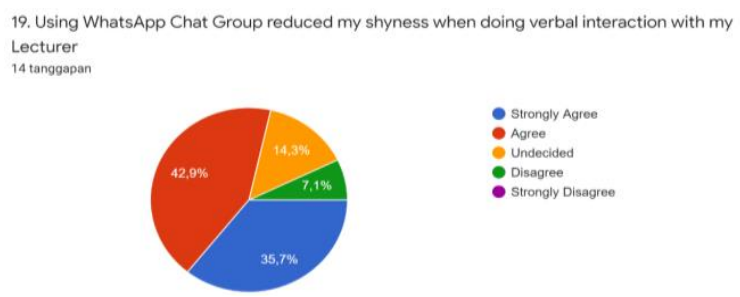

Chart 1. Shyness When Doing Verbal Interaction

Based on chart above, learners who used WhatsApp chat group dominantly chose agree $(50 \%)$. It described that learners can send and receive image, voice note, message even video through WhatsApp chat group. While, learners chose strongly agree lower than agree because there were some learners can receive image, voice note, message and video faster with adequate network. Then, learners chose strongly disagree, undecided and disagree because there were difficult to access network.

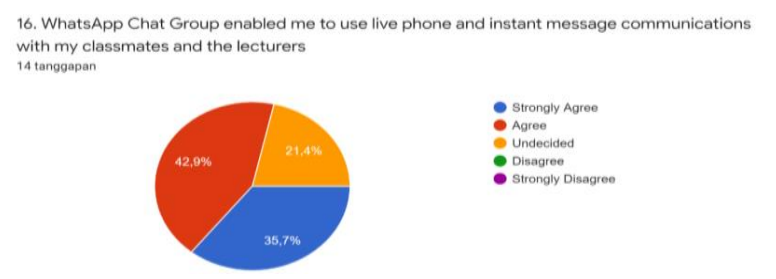

Chart 2. WhatsApp Chat Group Enabled to Use Live Phone 
From chart above, it stated that generally learners chose agree $(42,9 \%)$. This caused that features of WhatsApp chat group enabled learners to use live phone and instant message to communicate both classmate and lecturer. Nevertheless, they chose more agree than strongly agree because there are some learners still confuse to comprehend material when get material in ppt through WhatsApp chat group. They still need to send personal message both lecturer and classmate.

\section{Respond}

Items relating to respond including answer questions were analyzed as follow as:

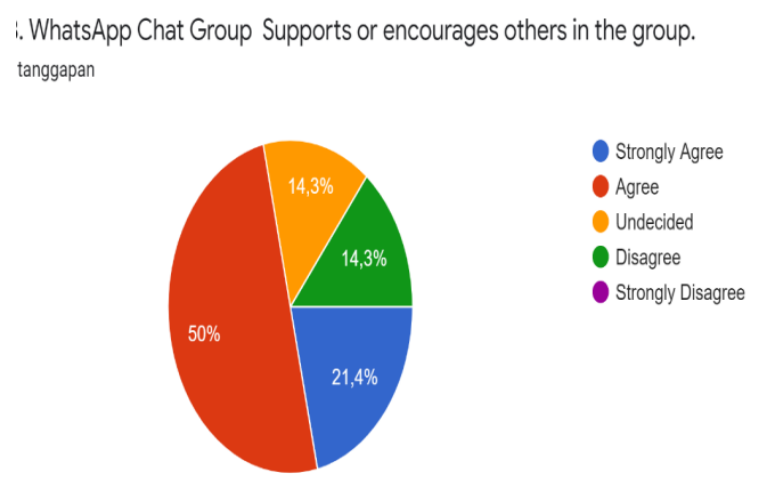

Chart 3. WhatsApp Chat Group Supports Others

Chart above stated that learners usually and every time to communicate with lecturer about material. When student had a bad network, s(he) can send their respond later when adequate network. It made them being flexible to communicate through WhatsApp chat group.

2. WhatsApp Chat Group enabled me to communicate with my lecturer about teaching and learning process

14 tanggapan

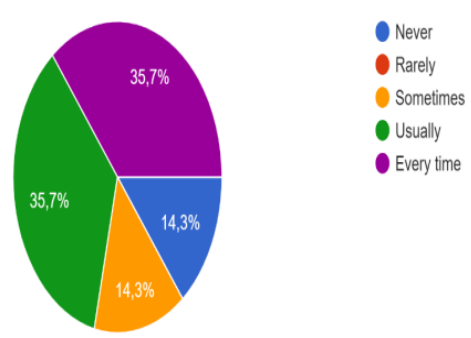

Chart 4. WhatsApp Chat Group Enabled to Communicate with Lecturer
From chart above, it described that learners dominantly chose agree 42,9\%) in using WhatsApp chat group to reduce shyness. This caused they were nervous to respond questions' lecturer in front of classmates and lecturers. They were fear to get ridicule from classmates dominantly chose agree.

20. WhatsApp Chat Group enabled me to express my opinions and thoughts more freely than in face- to -face discussions with my lecturer.

14 tanggapan
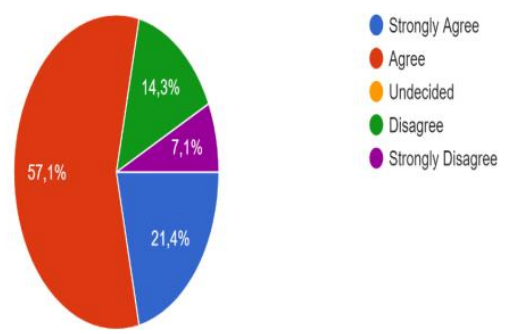

Chart 5. WhatsApp Chat Group Expressed Opinion

As described above, learners chose agree $(57.1 \%)$ to express opinions and thoughts more freely than in face-to-face discussion with lecturers. This explained that there was motivation and interest built by learners through WhatsApp chat group. Teaching learning process through WhatsApp chat group opened learners' knowledge to express opinion because they can connect directly with other reference such as google.

\section{Follow up}

Items of follow up were analyzed as follow as:

WhatsApp Chat Group helped me to increase my confidence level anggapan

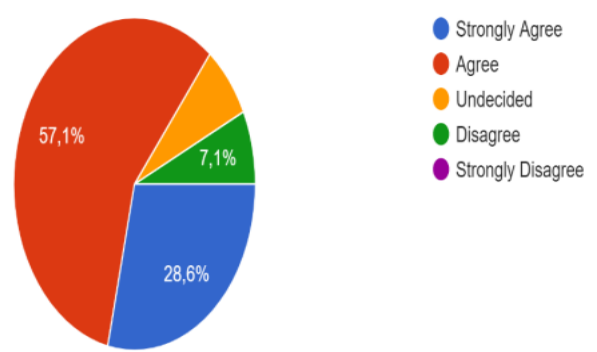

Chart 6. WhatsApp Chat Group Increased Confidence

From chart above, it described that learners dominantly chose agree $(50 \%)$ to get immediately feedback from to get 
immediately feedback from their lecturer. This caused that learners can receive any comment with rapid reply in WhatsApp chat group. In addition, lecturers gave revision of learners' assignment.

Other learners also could comprehend material when they did not understand previously. This facilitated a lecturer to avoid forwarding a message to other learners. As described in chart above, learners choose dominantly agree $(50 \%)$ in which WhatsApp chat group could support and encourage other learners in group. This was caused that there was a cooperative built by classmate in WhatsApp chat group. There was an inspiring from classmate that could stimulate to share ideas when teaching learning process took place through WhatsApp chat group.

The initiation is the first move in the verbal interaction. From questionnaire and observation through WhatsApp chat group, learners could receive material in the form of power point through WhatsApp chat group. After lecturers explaining material, learners asked question about material that make them confuse. They usually sent message and voice note if their statement was long. For example, "what is the example maám?". I don't understand the third slide sir?". Those chat stimulated classmate to help answering question. Voice note becomes a good featured of WhatsApp chat group that can be used as tool of verbal interaction between learners and lecturers. This is line with voice message chat conducted by (Minalla, 2018c) was appropriate platform to enrich verbal interaction outside classroom. Furthermore, (Nurazizah, Hega;Frihatin, L.Y;Sugiarto, 2019) said that voice note was effective tool which providing student's motivation to speak English actively through WhatsApp. It is one of direction to delivering material beside of message, audio and image. There is an instant message used to invite other learners participating when teaching and learning taking place. Therefore, initiation can occur through WhatsApp chat group that enabled learners to do verbal interaction.
Respond move was found that learners feel comfortable to communicate both lecturers and classmates through WhatsApp chat group. It was seemed that learners can reduce their fear or shyness to respond teachers' question. For example, "what is your opinion?". When lectures had sent material, mostly of student respond, "Yes maám", Yes sir". WhatsApp chat group stimulated all learners to participate by sending their ideas. Although it found that there were different ideas between them. Verbal interaction including respond answer of teacher question could create new information. This information could explore discussion. In addition, benefit of verbal interaction through WhatsApp chat group is emotion. Interaction between lectures-learners and student-learners can be closely. Learners have a chance every time to communicate with lecture. (Ta'amneh, 2017) stated that Whats App stimulated motivation, made eager to communicate with classmates and lecturer in order to make them feel relaxed, funny to chat without fear of making mistake. In addition, (Wijayanti \& Gunawan, 2019) revealed that utilization of WhatsApp could reduce shy learners that became the center of attention when participating in learning virtual vocabulary.

By through WhatsApp chat group, it was found that there was follow up move. Learners could get comment immediately both lecturer and learners. The content of comments could be read by members of WhatsApp chat group. So that there was not misunderstood occurring in the group. This comment can enable to build communicate especially verbal interaction through WhatsApp chat group. In addition, there acknowledgement such as "Good" that can give motivation and interest for learners to participate in WhatsApp chat group when teaching and learning process taking place. Next, WhatsApp chat group could give inspiring for learners when one of learners was still confused. Term of critizing was obtained by observation that a student gave comment of incorrect respond. For example, "scroll up, so you can see it". 
By the result of observation obtained through WhatsApp chat group, this gives positive feedback on verbal interaction. Lectures can develop their discussion with students by adopting selected material. As examples of lesson is morphology conducted as a research. In this virtual learning, students share and exchange ideas about word formation, built self confidence to send ideas by using voice note, instant message and sending image form of word formation (Bri et al., 2009; Pan et al., 2006; Stiles, 2000; Stonebraker \& Hazeltine, 2004). Furthermore, comment is also provided through WhatsApp chat group in order to revise the student's mistake in giving ideas related to word formation. Those students' behavior describe verbal interaction through WhatsApp chat group.

The verbal interaction has impact on teaching and learning process (Richardson et al., 2005). In the midst of covid-19 pandemic, all learning focuses on virtual learning in which traditional learning in the classroom is not used again. Nevertheles the objective of learning can be implemented and achieved. WhatsApp chat group can be used to teach many skills such as vocabulary, speaking, and writing. This is related to (Jafari \& Chalak, 2016)) revealed that WhatsApp can enhance students' skill and as become useful learning media to build interest and students' engagement in virtual learning.

\section{CONCLUSION AND RECOMMENDATION}

There is verbal interaction found including initiation, respond and follow up move. Initiation seems same as verbal interaction in the classroom including question written power point, directing and inviting presented by voice note, instant message. Then, mostly learners can find the responses by using communication through WhatsApp chat group. They can communicate and respond every time with lecturers and exchange ideas with classmates. By WhatsApp chat group, it was found to follow up. It seems that there is acknowledgement, comment and coitizing.
Nevertheless, it is not found ignoring, inform and prompt through WhatsApp chat group. By the result of research, it is found that learners' perception about verbal interaction give positive contribution through WhatsApp chat group. This proves that mostly learners choose agree with utilizing WhatsApp chat group in doing verbal interaction. Therefore, it is recommended that EFL lecturers provides enough opportunities and creative ways for the learners in teaching and learning process, also can improve their interaction during verbal interaction in the classroom and outside classroom through WhatsApp chat group or other online learning. This study could help and give the more information about classroom interaction, especially for further study. The further study can develop this study by using different variable, object, and online learning.

\section{REFERENCES}

Bri, D., García, M., Coll, H., \& Lloret, J. (2009). A study of virtual learning environments. WSEAS Transactions on Advances in Engineering Education, 6(1), 33-43.

Brown, H. D. (2001). Teaching by Principle: An Interactive Approach to Language. Pedagogy (second). New York: Pearson Education. Company.

Creswell, J. W. (2009). Research Design: Qualitatif, Quantitative, and Mixed Methods Approaches. Third Edition (Terjemahan) 2013 Research Design: Pendekatan Kualitatif, Kuantitatif, dan Mixed. (Third Edit). Yogyakarta: Pustaka Pelajar.

Downer, J., Sabol, T. J., \& Hamre, B. (2010). Teacher-child interactions in the classroom: Toward a theory of withinand cross-domain links to children's developmental outcomes. Early Education and Development, 21(5), 699-723.

Eliasoph, N., \& Lichterman, P. (2003). Culture in interaction. American 
Journal of Sociology, 108(4), 735794.

Harahap, H. S., Kurniawati, D. I., \& Komunikasi, S. (2018). Whatsapp Sebagai Media Strategi Komunikasi Ustadzah dalam Menyampaikan Dakwah (Studi Deskriptif Kulaitatif Komunitas "Belajar Islam Seru). Proceeding, DiMCC Conference, 1, 131-150.

Hymes, D. (2005). Models of the interaction of language and social life: Toward a descriptive theory. Intercultural Discourse and Communication: The Essential Readings, 4-16.

Jafari, S., \& Chalak, A. (2016). The Role of WhatsApp in Teaching Vocabulary to Iranian EFL Learners at Junior High School. 9(8), 85-92. https://doi.org/10.5539/elt.v9n8p85

Khaled Abdel Jaleel Dweikat. (2019). EFL Students' Perceptions of Whatsapp And Its Potential Benefits In ELT Practicum. Palestinian Journal of Technology \& Applied Sciences, 2(1), 14-29.

Kootbodien, A., Prasad, N. V., \& Ali, M. S. B. S. (2018). Trends and impact of WhatsApp as a mode of communication among Abu Dhabi students. Media Watch, 9(2), 257-266. https://doi.org/10.15655/mw/2018/v9i 2/49380

Lim, S., Park, K. C., Ha, M., Lee, H., \& Kim, Y. (2019). Verbal interaction types in science inquiry activities by group size. Eurasia Journal of Mathematics, Science and Technology Education, 15(7).

https://doi.org/10.29333/ejmste/10616 4

Mardiana, F., Zainuddin, Z., \& Gultom, J. J. (2019). Verbal Interaction in English Classroom Using Flanders Interaction Analysis Categories System (Fiacs). GENRE Journal of Applied
Linguistics of FBS Unimed, 7(3). https://doi.org/10.24114/genre.v7i3.12 443

Minalla, A. A. (2018a). The Effect of WhatsApp Chat Group in Enhancing EFL Learners' Verbal Interaction outside Classroom Contexts. English Language Teaching, 11(3), 1-7.

Minalla, A. A. (2018b). The Effect of WhatsApp Chat Group in Enhancing EFL Learners' Verbal Interaction outside Classroom Contexts. English Language Teaching, 11(3), 1. https://doi.org/10.5539/elt.v11n3p1

Minalla, A. A. (2018c). The Effect of WhatsApp Chat Group in Enhancing EFL Learners' Verbal Interaction outside Classroom Contexts. English Language Teaching, 11(3), 1. https://doi.org/10.5539/elt.v11n3p1

Nurazizah, Hega;Frihatin, L.Y;Sugiarto, B. R. (2019). WhatsApp Voice Note in Speaking Class. 3(3), 343-357.

Okditazeini, V., \& Irwansyah, I. (2018). Ancaman Privasi dan Data Mining di Era Digital: Analisis Meta-Sintesis pada Social Networking Sites (SNS). Jurnal Studi Komunikasi Dan Media, 22(2), https://doi.org/10.31445/jskm.2018.22 0202

Pan, Z., Cheok, A. D., Yang, H., Zhu, J., \& Shi, J. (2006). Virtual reality and mixed reality for virtual learning environments. Computers \& Graphics, 30(1), 20-28.

Pielmeier, M., Huber, S., \& Seidel, T. (2018). Is teacher judgment accuracy of students' characteristics beneficial for verbal teacher-student interactions in classroom? Teaching and Teacher Education, 76, 255-266.

Richardson, M. J., Marsh, K. L., \& Schmidt, R. C. (2005). Effects of visual and verbal interaction on unintentional 
interpersonal coordination. Journal of Experimental Psychology: Human Perception and Performance, 31(1), 62.

Sham, M., Ali, S., \& Kootbodien, A. (2017). The Effectiveness of WhatsApp as an Interpersonal Communication Medium among Abu Dhabi University Students. International Journal of Media, Journalism and Mass Communications, 3(1), 11-19. https://doi.org/10.20431/24549479.0301002

Stiles, M. J. (2000). Effective learning and the virtual learning environment. Proceedings: EUNIS 2000-Towards Virtual Universities, Instytut Informatyki Politechniki Poznanskiej.

Stonebraker, P. W., \& Hazeltine, J. E. (2004). Virtual learning effectiveness. The Learning Organization.
Ta'amneh, M. A. A. A. (2017). The Effect of Using WhatsApp Messenger in Learning English Language among University Students. International Research in Education, 5(1), 143. https://doi.org/10.5296/ire.v5i1.10801

Taloko, J. L. (2011). Teacher-Student Classroom Verbal Interaction in Intensive Course Classes of An English Department Student . 29, 7079.

Wijayanti, A., \& Gunawan, Y. B. (2019). Students' Perceptions towards the Utilization Of "Whatsapp" for Vocabulary Teaching and Learning. $5(2)$, 78-91. https://doi.org/10.26555/adjes.v5i2.10 462

Yanfen, L., \& Yuqin, Z. (2010). A study of teacher talks in interactions in English classes. Chinese Journal of Applied Linguistics, 33(2), 76-86. 